\title{
Spatial Variations of Sea Level along the Egyptian Mediterranean Coast
}

\begin{abstract}
By Tarek M. El-Geziry ${ }^{*} \&$ Mohamed A. Said ${ }^{ \pm}$
This paper is based on hourly sea level data from six tide-gauges distributed over the Egyptian Mediterranean coast. These data are used to calculate the tidal characteristics, the spatial variations of the mean sea level, its annual rates of increase and seasonal variations. Twelve astronomical tidal constituents are constructed using the T_TIDE package. Along the coast, tides are of semidiurnal type, and the mean sea level increases from west to east with a difference of $35 \mathrm{~cm}$ between the two extremities. The sea level rate of increase varied between $1.0 \mathrm{~mm} / \mathrm{yr}$ (west) and $6.4 \mathrm{~mm} / \mathrm{yr}$ (east), with an overall average rate of $3.4 \mathrm{~mm} / \mathrm{yr}$. This is higher than the rates of the global and whole Mediterranean basins, but meanwhile is less than the rate of the eastern Mediterranean basin. The sea level examines a seasonal trend with usual lows in spring and highs in summer. The seasonal variations tend to be mostly affected by the air pressure scheme and wind regime over the coast. Land subsidence is another factor, which must be considered upon investigation of sea level variability along the Egyptian Mediterranean coast. However, this needs to be verified and concluded through more robust actual geological observations and analyses.
\end{abstract}

Keywords: Astronomical tides, Egypt, Mean sea level, Mediterranean Sea, Sea level rise, Seasonal variability.

\section{Introduction}

The Egyptian Mediterranean coast stretches over about $1200 \mathrm{~km}$ from Sallum ( $\left.31^{\circ} 30^{\prime} 13^{\prime \prime} \mathrm{N} ; 25^{\circ} 06^{\prime} 54^{\prime \prime} \mathrm{E}\right)$ in the west to Rafah $\left(31^{\circ} 17^{\prime} 19^{\prime \prime} \mathrm{N} ; 34^{\circ} 14^{\prime} 28^{\prime \prime} \mathrm{E}\right)$ in the east (Figure 1), comprising four different sections on the basis of the physiographical characteristics. Accordingly, different coastal dynamical features may be expected for investigation at each of these sections. The most western section (Section 1) is the northwest Egyptian Mediterranean region, which extends from Sallum to Alamein and is characterised by the highest elevation above the mean sea level (MSL) along the entire Egyptian Mediterranean coast (Santamaria and Farouk 2011). Section 2 presents the middle northern Egyptian Mediterranean region extending from Alamein to Alexandria, comprising Alexandria Western Harbour, the main Egyptian port on the Mediterranean. The third section is the Egyptian Nile Delta region, which extends from Rosetta to Port Said, where the highest population density inhibits and the main zone of Egypt agriculture

\footnotetext{
*Associate Research Professor, Laboratory of Physical Oceanography, Division of Marine Environment, National Institute of Oceanography and Fisheries (NIOF), Alexandria, Egypt. ${ }^{ \pm}$Emeritus Professor, Laboratory of Physical Oceanography, Division of Marine Environment, National Institute of Oceanography and Fisheries (NIOF), Alexandria, Egypt.
} 
activities exist. Lastly, the most eastern section (Section 4) is the north-eastern Egyptian Mediterranean region, which extends from Port Said to Rafah comprising the main zone of Egypt industrial and commercial activities, including the Suez Canal. Along this prolonged coast, five coastal lakes in connection with the Mediterranean Sea take place. These are Mariut, Edku, Burullus, Manzalah and Bardawil from east to west, respectively. These Delta Lakes are key ecosystems that act as a protective zone for inland economic activities (UNDP 2014). In addition to this coastal lake system, the Egyptian Mediterranean coast is characterised by the existence of different ports and harbours, some of which are commercials, e.g., Alexandria, and others serve mainly fishermen societies, e.g., El-Burullus.

Figure 1. The Egyptian Mediterranean Coast with its Four Geographical Sections and Locations of the Six Tide Gauges Used in the Present Work

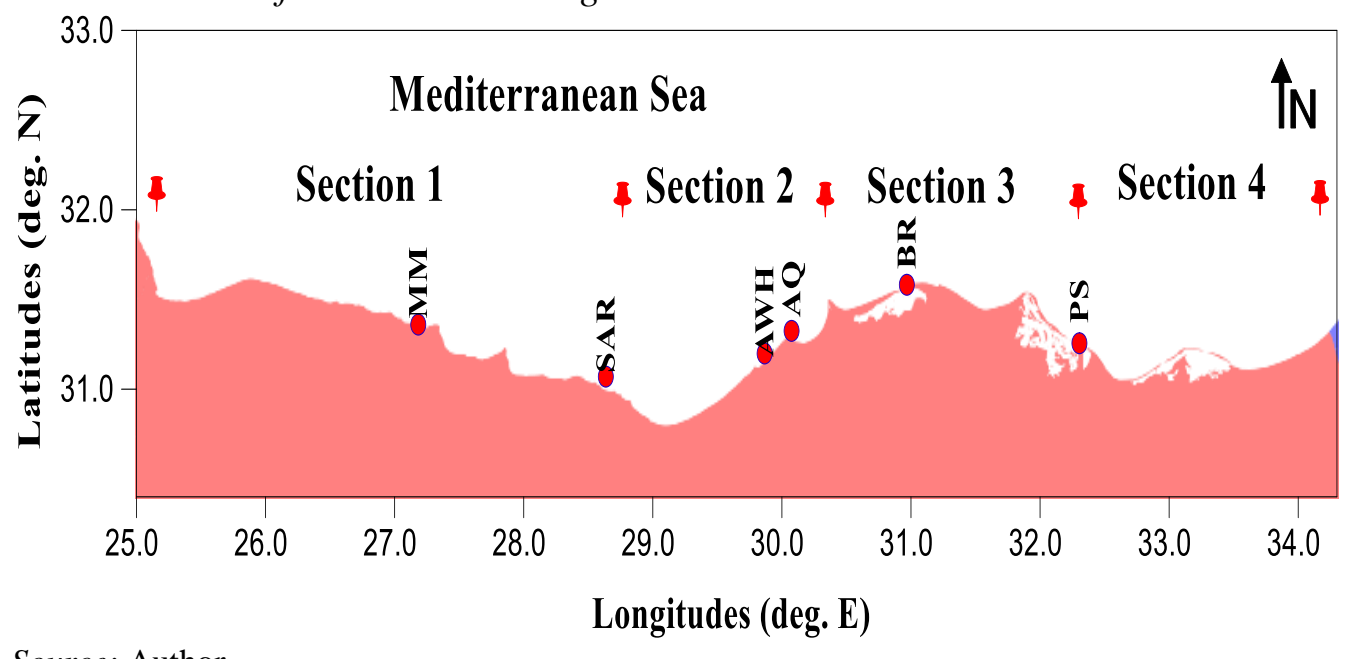

Source: Author.

The observed sea level variations in the Mediterranean Sea are attributed to both the meteorological conditions impacting on the internnual and higher frequencies changes (Gomis et al. 2006) and to the steric parameters influencing the regional changes (Tsimplis and Josey 2001). The sea level variations in the eastern Mediterranean basin, as in the whole basin, are driven by changes in the driving forces of climate and are affected by the anthropogenic factor. Within the Basin, the sea level decreased between 1960 and 1994 due to the increase in the atmospheric pressure (Tsimplis and Josey 2001), and the steric heights decreased as a result of cooling of the upper waters of the eastern Mediterranean (Tsimplis 2002). After 1993, warm air caused sea level in the eastern Mediterranean basin to rise (Tsimplis 2002). In the Levantine Basin, a SLR (sea level rise) of 10 $\mathrm{mm} / \mathrm{yr}$ off the Israeli coast during the period 1990-2001 was noticed by Shirman (2001). The same rate was revealed for the period 1992-2002 (Rosen, 2002). Larnicol et al. (2002) suggested that the changes observed in the sea level anomalies during the period 1995-1999 in the Levantine are related to variations in the deep and intermediate water masses distributions in the whole Eastern basin. By analysing hydrographic data (temperature and salinity) to investigate the sea 
level changes in the Mediterranean Sea, Tsimplis (2002) concluded that most of the sea level variability in the eastern Mediterranean basin during the last 5 decades is due to steric changes in the upper waters directly linked with cooling. Vigo et al. (2011) used 16-year altimetery data set (1992-2008) to investigate the sea level variations in the Mediterranean Sea. Their results revealed that the amplitudes of the annual cycle vary from 4 to $11 \mathrm{~cm}$, except for a small area of value around $16 \mathrm{~cm}$ at the south-east of Crete corresponding to the Ierapetra gyre activity. They concluded that the major features of the Mediterranean Sea circulation are driving the highest seasonal variability in the observed sea level. The thermosteric contribution in the observed sea level variations is also dominant in the Levantine Sea (Passaro and Seitz 2012).

The observed sea level variation off the Egyptian Mediterranean coast results mainly from the combination of the astronomical tides and surges. Tides, as in the whole Mediterranean basin, are mainly semidiurnal, with a general tidal range in the order of a few centimetres (Moursy 1994, Moursy 1998, Tayel 2008, Hussein et al. 2010, Saad et al. 2011, El-Geziry and Radwan 2012, Said et al. 2012, Radwan and El-Geziry 2013). Surges, on the other hand, have more impact on the Egyptian Mediterranean coast. They may reach $1.0 \mathrm{~m}$ elevation under the effect of the meteorological factors (El-Geziry and Radwan 2012). The combined impact of astronomical tides, storm surges and sea level rise (SLR) can severely affect lives and coastal properties (Douglas 2001). Off the Egyptian Mediterranean coast, the SLR rate has ranged between 2.0 and $3.0 \mathrm{~mm} / \mathrm{yr}$ over different periods (El-Fishawi and Fanos 1989, Frihy 1992, Frihy 2003, Shaker et al. 2011, and Maiyza and El-Geziry 2012). In addition to the SLR problem, the abovementioned four regions along the Egyptian Mediterranean Sea are shown to examine various environmental stresses that are mainly attributed to anthropogenic activities: urban, touristic, industrial and agricultural; resulting in pollutants of land-based sources (UNDP 2011). The environmental problems related to coastal development, the alteration of the coastline and borders of the wetlands and watersheds, and the biological threats are all characteristic of these sections (UNDP 2011, UNDP 2014). Erosion is an additional problem, particularly in the Delta zone, where engineering and constructive works are constantly required as a means of protection (Frihy 1992, Frihy and Lotfy 1994, Dasgupta et al. 2009, ElSharkawy et al. 2009, El-Raey 2010). The Egyptian Mediterranean coast has been identified as highly vulnerable to climate change induced SLR. Dasgupta et al. (2009) ranked Egypt in the top ten most impacted countries (out of 84 developing coastal countries considered world-wide) for population potentially displaced due to a $1 \mathrm{~m}$ sea-level rise. Studies on the vulnerability of Alexandria to SLR revealed that a $0.3 \mathrm{~m}$ increase in the sea level would inundate large parts of the city; resulting in infrastructure damage, in displacement of over 500000 citizens and in a loss of about 70000 work opportunities (El-Raey et al. 1999). Alexandria was also ranked $11^{\text {th }}$ in terms of population exposed to coastal flooding in 2070s (ElDeberky and Hunicke 2015). Syvitski et al. (2009) identified the Nile and Niger Deltas as being the most threatened of the African deltas due to land subsidence and human interference. 
All these factors reflecting the importance of monitoring the sea level variations along the Egyptian Mediterranean coast motivated this analysis of sea level, which includes, for the first time, a set of sea level data covering the whole Egyptian Mediterranean coast. Results from such research are necessary not only for monitoring sea level but also for preparing a mitigation program for coastal defence.

\section{Data and Methods of Analysis}

The present work is based on hourly sea level records from six tide gauges distributed over the Egyptian Mediterranean coast as shown in Figure (1). These gauges were deployed at Mersa Matrouh (MM), Sidi Abdel-Rahman (SAR), Alexandria Western Harbour (AWH), Abu-Qir Bay (AQ), Burullus new harbour (BR) and Port Said (PS) from west to east, respectively. The periods of data are different for each location (Table 1), with the longest records (30 years) at AWH and the shortest records (4 years) at MM. The recorded sea level at each location is referred to the zero level of the instrument.

Table 1. Location Names, Tide Gauge Positions and Periods of Records of Sea Level Data in the Present Study

\begin{tabular}{|c|c|c|c|c|c|}
\hline \multirow{2}{*}{ Location } & \multirow{2}{*}{ Nomination } & \multicolumn{2}{|c|}{$\begin{array}{c}\text { Tide Gauge } \\
\text { Position }\end{array}$} & \multirow{2}{*}{$\begin{array}{l}\text { Period of } \\
\text { Records }\end{array}$} & \multirow{2}{*}{$\begin{array}{c}\text { \% of Missed } \\
\text { Data }\end{array}$} \\
\hline & & $\begin{array}{l}\text { Lat. } \\
\left({ }^{\circ} \mathbf{N}\right)\end{array}$ & $\begin{array}{l}\text { Long. } \\
\left({ }^{\circ} \mathbf{E}\right)\end{array}$ & & \\
\hline $\begin{array}{l}\text { Mersa } \\
\text { Matrouh }\end{array}$ & MM & 31.360 & 27.183 & $\begin{array}{c}4 \text { years } \\
(2003-2006) \\
\end{array}$ & 0 \\
\hline $\begin{array}{l}\text { Sidi Abdel- } \\
\text { Rahman }\end{array}$ & SAR & 31.070 & 28.836 & $\begin{array}{c}5 \text { years } \\
(2012-2016)\end{array}$ & 0 \\
\hline $\begin{array}{l}\text { Alex. } \\
\text { Western } \\
\text { Harbour }\end{array}$ & AWH & 31.183 & 29.983 & $\begin{array}{c}33 \text { years } \\
(1974-2006)\end{array}$ & 9.1 \\
\hline Abu-Qir Bay & AQ & 31.325 & 30.075 & $\begin{array}{c}21 \text { years } \\
(1990-2010)\end{array}$ & 0 \\
\hline Burullus & BR & 31.582 & 30.986 & $\begin{array}{c}6 \text { years } \\
(2003-2008)\end{array}$ & 0 \\
\hline Port Said & PS & 31.256 & 32.305 & $\begin{array}{c}8 \text { years } \\
(2003-2010)\end{array}$ & 0 \\
\hline
\end{tabular}

Source: Author.

The sea level records were analysed; in order to get the astronomical tidal constituents; using the T_TIDE package (Pawlowicz et al. 2002), which works under the Matlab ${ }^{\circledR}$ environment. T_TIDE is principally based on the concept of the ability of expressing the tidal amplitudes at any location as the sum of all the harmonic components: 


$$
\eta(t)=\sum_{n} A_{n} \cos \left(\frac{2 \pi}{T_{n}} t+\phi_{n}\right)
$$

Where,

$\eta(\mathrm{t})$ vertical displacement of the sea surface as a function of time (m)

$\mathrm{A}_{\mathrm{n}}$ amplitude of a harmonic component (m)

$\mathrm{T}_{\mathrm{n}}$ period of a harmonic component (s)

$\varphi_{\mathrm{n}}$ phase of harmonic component

The T_TIDE package may give up to 68 tidal constituents. A signal-to-noise power ratio (SNR) is computed based on the square of the ratio of amplitude to amplitude error, and is used to identify significant constituents. The latter (those with SNR > 1) are marked with a "*” in the result sheet of the T_TIDE analysis (Pawlowicz et al. 2002). As tidal amplitudes in the Mediterranean Sea are of a few centimetres, the present work focuses only on the 12 major tidal components for all: diurnal, semidiurnal and long period oscillations. These are defined, according to Kowalik and Luick (2013) in Table 2.

Table 2. The 12 Major Tidal Constituents Generated Using the T_Tide Package in the Present Study

\begin{tabular}{|l|c|c|}
\hline Diurnal Constituents & Semidiurnal Constituents & $\begin{array}{c}\text { Long period } \\
\text { Constituents }\end{array}$ \\
\hline $\begin{array}{l}\mathrm{O}_{1} \text { Principal lunar } \\
\text { diurnal }\end{array}$ & $\begin{array}{c}\mathrm{M}_{2} \text { Pricipal lunar } \\
\text { semidiurnal }\end{array}$ & Mf Lunar fortnightly \\
\hline $\mathrm{K}_{1}$ Lunisolar diurnal & $\begin{array}{c}\mathrm{S}_{2} \text { Principal solar } \\
\text { semidiurnal }\end{array}$ & Mm Lunar monthly \\
\hline $\mathrm{P}_{1}$ Principal solar diurnal & $\mathrm{N}_{2}$ Lunar elliptic semidiurnal & Sa Solar annual \\
\hline $\mathrm{Q}_{1}$ Larger lunar elliptic & $\mathrm{K}_{2}$ Lunisolar semidiurnal & Ssa Solar semiannual \\
\hline
\end{tabular}

Source: Kowalik and Luick (2013).

The Mean Sea Level (MSL) is often defined as the average value of levels observed each hour over a period of at least a year, and preferably over about 19 years, to average over the cycles of 18.61 years in the tidal amplitudes and phases, and to average out weather (Pugh and Woodworth 2014). According to this definition, the MSL is calculated in the present study based on the hourly sea level sets. On the basis of the calculated MSL, together with the obtained astronomical constituents: principal semidiurnal (M2 and S2) and main diurnal (K1 and O1), the terms describing the main tidal characteristics (Moursy 1994, 1998) along the southern Levantine Basin were calculated. This comprises the highest high water level (HHWL), the lowest low water level (LLWL), the mean high water spring (MHWS), the mean low water spring (MLWS), the mean high water neap (MHWN) and the mean low water neap (MLWN).

Moreover, the type of tides along the Egyptian Mediterranean coast was determined using the constituent factor (Pugh 2004). According to the value of the $\mathrm{F}$ factor, the type of a tides can be defined as follows: if $\mathrm{F}$ ranges between 0 
and 0.25 then a semidiurnal cycle results; if $F$ ranges between 0.25 and 1.25 then a mixed mainly semidiurnal tide occurs; if $F$ ranges from 1.25 to 3 then a mixed mainly diurnal tide occurs and finally a diurnal tide results for $\mathrm{F}$ values great than 3 (Pugh 2004).

$\mathrm{FF}=\left(\mathrm{H}_{\mathrm{O} 1}+\mathrm{H}_{\mathrm{K} 1}\right) /\left(\mathrm{H}_{\mathrm{M} 2}+\mathrm{H}_{\mathrm{S} 2}\right)$

Where,

$\mathrm{H}_{\mathrm{O} 1}$ is the principal lunar diurnal constituent amplitude;

$\mathrm{H}_{\mathrm{K} 1}$ is the luni-solar diurnal constituent amplitude;

$\mathrm{H}_{\mathrm{M} 2}$ is the principal lunar semidiurnal constituent amplitude; and

$\mathrm{H}_{\mathrm{S} 2}$ is the principal solar semidiurnal constituent amplitude

Annual and monthly mean levels were calculated for each data set to present the final results and discussion in the present work.

\section{Results}

Tidal Characteristics along the Egyptian Mediterranean Coast

Table 3 shows the constructed twelve constituents' amplitudes and phases at each investigated location in the present study. Despite the weakness of the observed astronomical tides along the coast, the $\mathrm{M}_{2}$ constituent is still the key player in the observed variations in the astronomical tides, as in the worldwide known places of semidiurnal tides. The $\mathrm{M}_{2}$ amplitude has its minimum value (0.6 $\mathrm{cm})$ at SAR and its maximum value in PS $(13 \mathrm{~cm})$. Sidi Abdel-Rahman location has the lowest astronomical tidal elevations among the six investigated locations. This may be attributed to the deployment location of tide gauge, which is an enclosed bay with a narrow opening connection to the open sea. The obtained information on the astronomical elevations was used to calculate the different water level characteristics along the Egyptian Mediterranean coast. The results are shown in Table (4). It can be easily deduced that tides along the Egyptian Mediterranean coast are of mainly semidiurnal type. While the highest HHWL occurred at PS $(87 \mathrm{~cm})$, the lowest LLWL occurred at MM $(23 \mathrm{~cm})$. PS and SAR had the maximum and minimum values, respectively, for both the spring and the neap water ranges.

\section{The Spatial Pattern of the Mean Sea Level (MSL)}

The spatial variations of the MSL along the Egyptian Mediterranean coast are presented in Table 4. The MSL increases all the way long from MM to PS, i.e. from west to east, with a total difference of $35 \mathrm{~cm}$ between the two extremities. AQ and AWH have the same MSL of $48 \mathrm{~cm}$, which is in good agreement with previously calculated MSL at the two locations over different periods (Saad et al. 2011, El-Geziry and Radwan 2012, Said et al. 2012, El-Geziry 2013). The 
present MSL slope along the Egyptian Mediterranean coast agrees with the general atmospheric pressure scheme over the Levantine Basin (Tsimplis et al. 2005, Gomis et al. 2008, Oddo et al. 2014).

\section{Spatial Variations of the Annual MSL (Sea Level Rates)}

The annual MSL variability and trends at the six tide gauge locations along the Egyptian Mediterranean coast are shown in Figure 2. Results revealed a general trend of increase in the annual MSL along the Egyptian Mediterranean Coast but with different rates. It can be deduced that the regions of sections 3 and 4, comprising the Nile Delta, examine the highest rates of increase being 4.8 $\mathrm{mm} / \mathrm{yr}, 3.8 \mathrm{~mm} / \mathrm{yr}$ and $6.4 \mathrm{~mm} / \mathrm{yr}$ at PS, BR and AQ, respectively. On the other hand, the three other rates of increase are $2.2 \mathrm{~mm} / \mathrm{yr}, 1.0 \mathrm{~mm} / \mathrm{yr}$ and $2.4 \mathrm{~mm} / \mathrm{yr}$ at AWH, SAR and MM, respectively. The average rate of the SLR along the Egyptian Mediterranean coast is $3.4 \mathrm{~mm} / \mathrm{yr}$. This is larger than the global SLR rate for the $20^{\text {th }}$ century of $1.8 \pm 0.5 \mathrm{~mm} / \mathrm{yr}$ (Church and White 2006, 2011) and for the whole Mediterranean basin rates, over the same period, of 1.1-1.3 mm/yr (Tsimplis and Baker 2000). Meanwhile, it is less than the Eastern Mediterranean rates of 04-20 mm/yr (Cazenave et al. 2001, Rosen 2002, Klein et al. 2004, Tsimplis et al. 2008, Vigo et al. 2011, Passaro and Seitz 2012).

\section{Spatial Variations of the Seasonal Sea Level Variations}

The seasonality in the recorded sea level is a major cause of its observed variability (Torres and Tsimplis 2012). Different coastal regions can be influenced by different meteorological and oceanographic factors, such as atmospheric pressure, wind system and the thermohaline steric effects (Gill and Niiler 1973). Along the Egyptian Mediterranean coast, previous studies in the seasonal variability of sea level are scarce, although this is important for coastal risk assessments and mitigation plan initiation to face risks from SLR, storm surges and floods. Monthly mean variations of sea levels along the Egyptian Mediterranean coast based on the present data sets are shown in Figure 3. This shows that the sea level along the Egyptian Mediterranean coast examines a seasonal trend with usual low values in March and April (spring season) and higher ones in August (summer season), except at Sidi Abdel-Rahman, where the maximum mean monthly sea level was in December. November and December (late autumn/early winter seasons) also examines high mean monthly values. The seasonal sea level variability along the Egyptian Mediterranean coast can thus be concluded to be consistent with the atmospheric pressure scheme over the coast and the wind regime. 
Table 3. The Twelve Constituents' Amplitudes and Phases at Each Investigated Tide Gauge Location

\begin{tabular}{|c|c|c|c|c|c|c|c|c|c|c|c|c|c|c|c|c|c|c|c|c|c|c|c|c|c|}
\hline & Freq. & \multicolumn{4}{|c|}{ MM } & \multicolumn{4}{|c|}{ SAR } & \multicolumn{4}{|c|}{ AWH } & \multicolumn{4}{|c|}{$\mathrm{AQ}$} & \multicolumn{4}{|c|}{ BR } & \multicolumn{4}{|c|}{ PS } \\
\hline & & $\begin{array}{c}\mathrm{A} \\
(\mathrm{cm})\end{array}$ & $\begin{array}{l}\text { Amp. } \\
\text { Error }\end{array}$ & $\phi^{\left({ }^{\circ}\right)}$ & $\begin{array}{l}\text { Phase } \\
\text { Error }\end{array}$ & $\begin{array}{c}\mathrm{A} \\
(\mathrm{cm})\end{array}$ & $\begin{array}{l}\text { Amp. } \\
\text { Error }\end{array}$ & $\phi^{\left({ }^{\circ}\right)}$ & $\begin{array}{l}\text { Phase } \\
\text { Error }\end{array}$ & $\begin{array}{c}\mathrm{A} \\
(\mathrm{cm})\end{array}$ & $\begin{array}{l}\text { Amp. } \\
\text { Error }\end{array}$ & $\phi^{\left({ }^{\circ}\right)}$ & $\begin{array}{l}\text { Phase } \\
\text { Error }\end{array}$ & $\begin{array}{c}\mathrm{A} \\
(\mathrm{cm})\end{array}$ & $\begin{array}{l}\text { Amp. } \\
\text { Error }\end{array}$ & $\phi^{\left({ }^{\circ}\right)}$ & $\begin{array}{l}\text { Phase } \\
\text { Error }\end{array}$ & $\begin{array}{c}\mathrm{A} \\
(\mathrm{cm})\end{array}$ & $\begin{array}{l}\text { Amp. } \\
\text { Error }\end{array}$ & $\phi^{\left({ }^{\circ}\right)}$ & $\begin{array}{l}\text { Phase } \\
\text { Error }\end{array}$ & $\begin{array}{c}\mathrm{A} \\
(\mathrm{cm})\end{array}$ & $\begin{array}{l}\text { Amp. } \\
\text { Error }\end{array}$ & $\phi^{\left({ }^{\circ}\right)}$ & $\begin{array}{l}\text { Phase } \\
\text { Error }\end{array}$ \\
\hline SA & 0.000114 & 4.0 & 0.80 & 312 & 11.46 & 4.0 & 0.79 & 312 & 12.51 & 9.0 & 1.30 & 334 & 7.94 & 5.7 & 0.80 & 327 & 8.48 & 6.8 & 0.90 & 336 & 7.93 & 9.8 & 0.13 & 344 & 6.59 \\
\hline SSA & 0.000228 & 2.4 & 0.80 & 332 & 18.71 & 2.4 & 0.80 & 332 & 9.00 & 2.5 & 1.30 & 318 & 29.11 & 2.6 & 0.80 & 313 & 18.58 & 4.0 & 0.90 & 290 & 13.42 & 6.5 & 0.13 & 305 & 9.98 \\
\hline MM & 0.001512 & 1.2 & 0.80 & 191 & 73.94 & 1.2 & 0.80 & 191 & 74.03 & 0.3 & 1.30 & 177 & 119.85 & 2.2 & 0.80 & 128 & 17.02 & 1.8 & 0.90 & 12 & 96.10 & 1.7 & 0.13 & 249 & 189.92 \\
\hline $\mathrm{MF}$ & 0.00305 & 2.8 & 0.80 & 118 & 60.96 & 2.8 & 0.79 & 118 & 60.94 & 0.7 & 1.30 & 92 & 6.65 & 2.0 & 0.80 & 110 & 42.70 & 2.0 & 0.90 & 58 & 72.29 & 2.6 & 0.13 & 67 & 46.03 \\
\hline $\mathrm{Q}_{1}$ & 0.037219 & 0.8 & 0.15 & 12 & 94.08 & 0.8 & 0.15 & 12 & 94.10 & 0.1 & 0.10 & 272 & 44.45 & 0.6 & 0.13 & 13 & 7.63 & 0.5 & 0.13 & 280 & 119.42 & 0.4 & 0.14 & 257 & 150.27 \\
\hline $\mathrm{O}_{1}$ & 0.038731 & 0.2 & 0.15 & 257 & 40.24 & 0.1 & 0.15 & 258 & 42.00 & 1.0 & 0.10 & 326 & 3.88 & 0.9 & 0.13 & 304 & 67.67 & 1.2 & 0.13 & 245 & 51.61 & 1.2 & 0.14 & 259 & 56.84 \\
\hline$P_{1}$ & 0.041553 & 0.1 & 0.15 & 41 & 72.81 & 0.1 & 0.15 & 41 & 72.83 & 0.5 & 0.10 & 257 & 9.09 & 1.0 & 0.13 & 51 & 70.57 & 1.1 & 0.13 & 20 & 68.56 & 1.0 & 0.14 & 15 & 74.28 \\
\hline $\mathrm{K}_{1}$ & 0.041781 & 0.4 & 0.15 & 34 & 21.56 & 0.5 & 0.15 & 335 & 21.60 & 1.4 & 0.10 & 355 & 3.10 & 0.3 & 0.13 & 344 & 20.89 & 3.3 & 0.13 & 13 & 20.30 & 3.2 & 0.14 & 8 & 21.99 \\
\hline $\mathrm{N}_{2}$ & 0.078999 & 1.1 & 0.13 & 54 & 76.30 & 0.1 & 0.14 & 267 & 75.90 & 0.7 & 0.20 & 20 & 14.74 & 0.4 & 0.07 & 19 & 102.50 & 0.4 & 0.08 & 264 & 108.35 & 0.3 & 0.08 & 261 & 145.34 \\
\hline $\mathrm{M}_{2}$ & 0.080511 & 5.2 & 0.13 & 54 & 9.99 & 0.6 & 0.14 & 281 & 10.10 & 5.2 & 0.20 & 245 & 42.10 & 2.0 & 0.07 & 234 & 12.04 & 3.7 & 0.08 & 326 & 12.82 & 13.5 & 0.08 & 323 & 13.84 \\
\hline $\mathrm{S}_{2}$ & 0.083333 & 3.2 & 0.14 & 322 & 15.23 & 0.5 & 0.14 & 316 & 15.03 & 2.9 & 0.20 & 310 & 3.58 & 1.3 & 0.07 & 307 & 15.31 & 2.0 & 0.08 & 247 & 22.45 & 2.2 & 0.08 & 250 & 20.85 \\
\hline $\mathrm{K}_{2}$ & 0.083562 & 0.3 & 0.14 & 87 & 21.91 & 0.3 & 0.14 & 87 & 22.01 & 0.8 & 0.20 & 333 & 10.10 & 0.7 & 0.07 & 345 & 43.16 & 0.6 & 0.08 & 270 & 63.32 & 0.6 & 0.08 & 273 & 58.81 \\
\hline
\end{tabular}

Source: Author. 
Table 4. Tidal Characteristics along the Egyptian Mediterranean Coast

\begin{tabular}{|l|c|c|c|c|c|c|}
\hline & MM & SAR & AWH & AQ & BR & PS \\
\hline FF & 0.10 & 0.45 & 0.30 & 0.37 & 0.79 & 0.28 \\
\hline MSL (cm) & 32 & 35 & 48 & 48 & 62 & 67 \\
\hline HHWL (cm) & 41 & 37 & 57 & 53 & 72 & 87 \\
\hline LLWL (cm) & 23 & 33 & 37 & 43 & 52 & 47 \\
\hline MHWS (cm) & 40 & 36 & 55 & 51 & 68 & 83 \\
\hline MLWS (cm) & 24 & 34 & 39 & 45 & 56 & 51 \\
\hline Spring range (cm) & 16 & 2 & 16 & 6 & 12 & 32 \\
\hline MHWN (cm) & 34 & 35 & 49 & 49 & 64 & 78 \\
\hline MLWN (cm) & 30 & 34 & 45 & 47 & 60 & 56 \\
\hline Neap range (cm) & 4 & 1 & 4 & 2 & 4 & 22 \\
\hline
\end{tabular}

Source: Author.

Figure 2. Annual MSL and Trends along the Egyptian Mediterranean Coast

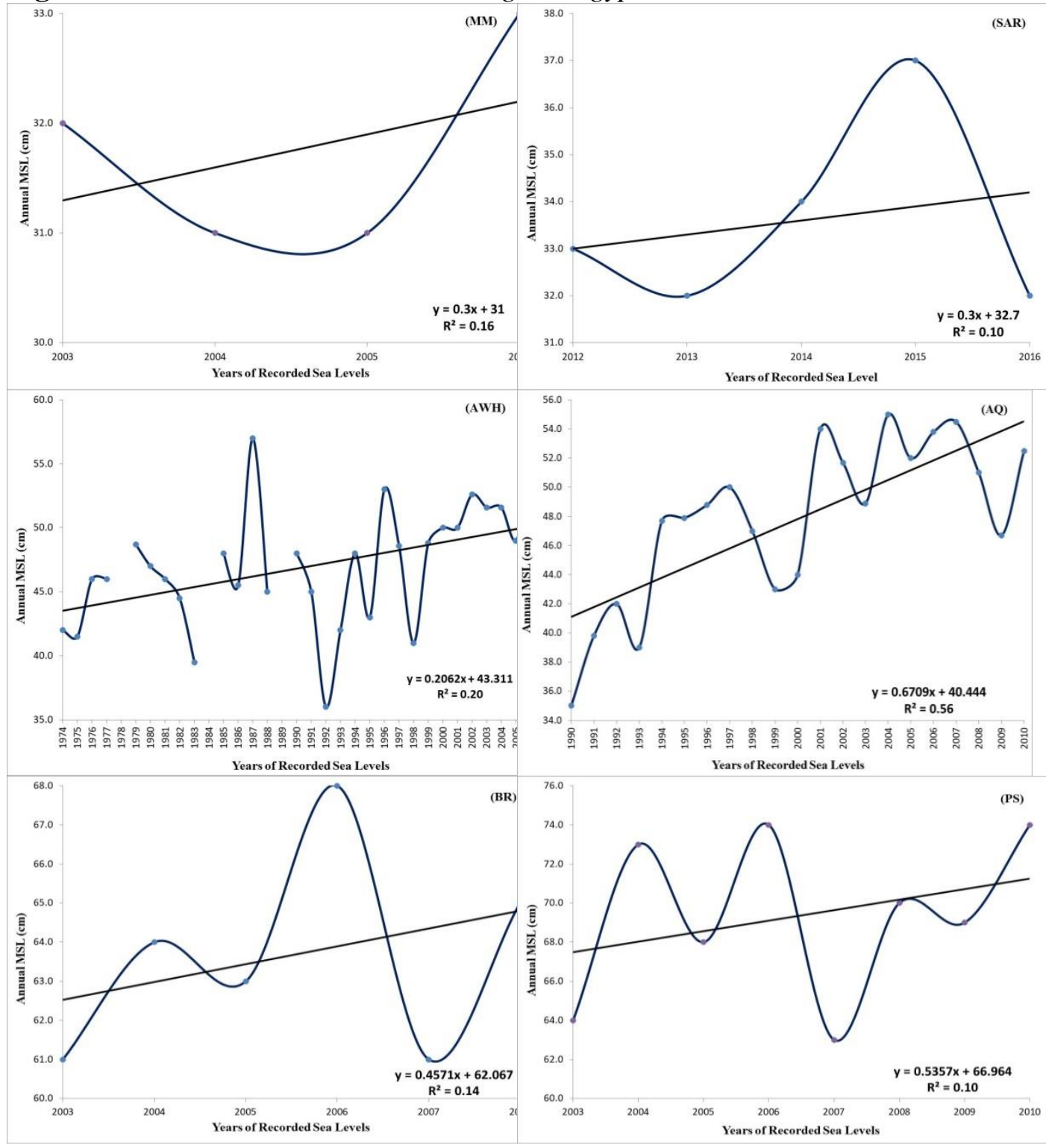


Figure 3. Seasonal Variability in the Recorded Sea Levels along the Egyptian Mediterranean Coast

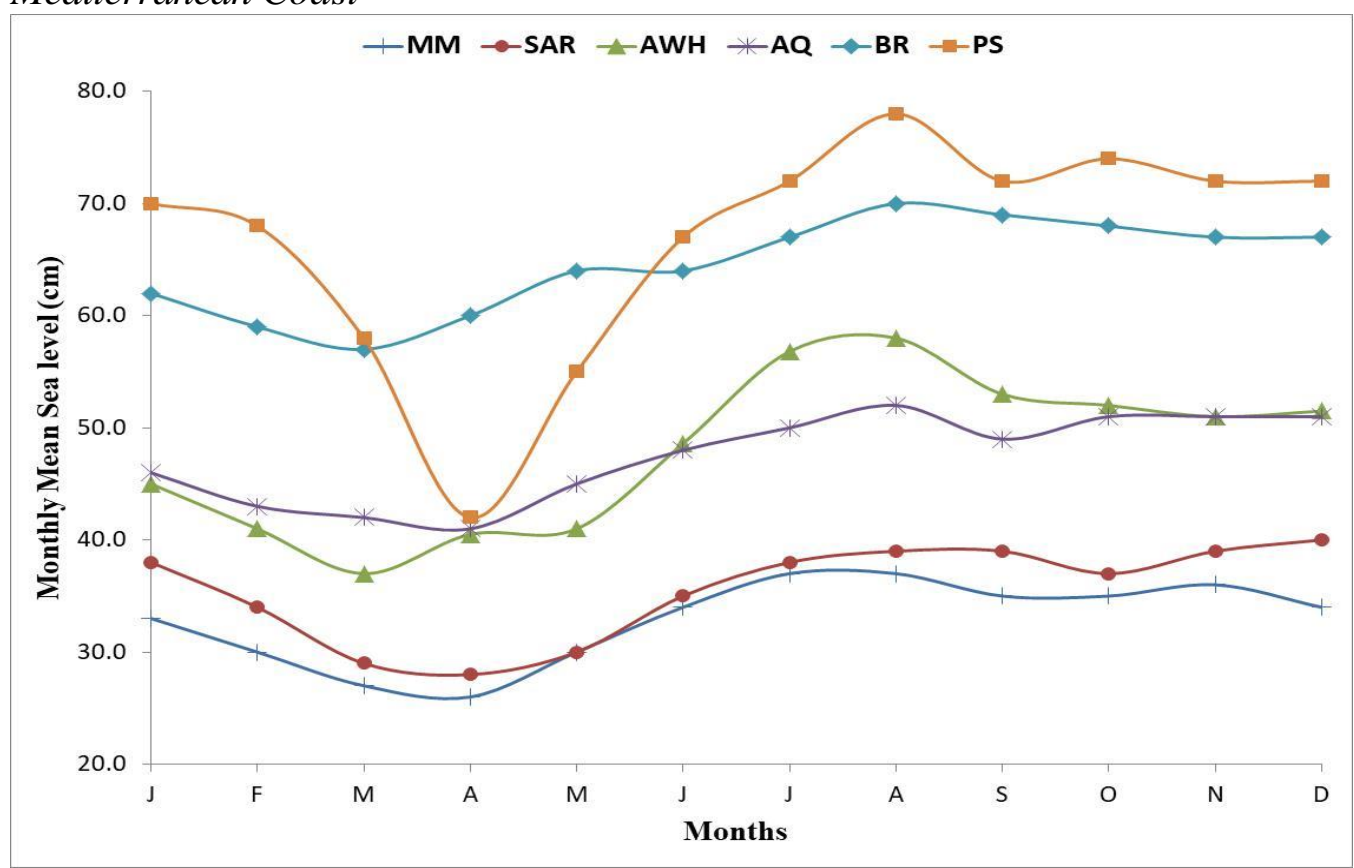

Source: Author.

\section{Discussion and Conclusion}

Sea level data from six tide gauges were used to study four aspects of coastal sea level: (1) Tidal characteristics, (2) Spatial variations of the MSL, (3) Annual rates of variations in the MSL and (4) Seasonal variations of sea level, along the Egyptian Mediterranean coast. The study analysed more extensive data than previous studies along this coast.

The T_TIDE package was used to produce the twelve major tidal constituents. Results revealed that astronomical tides along the Egyptian Mediterranean coast are of mainly semidiurnal type with amplitudes in order of a few centimetres. The amplitudes of the solar annual constituent (Sa) ranging between 4.0 and $9.8 \mathrm{~cm}$ along the Egyptian Mediterranean Coast are in agreement with Vigo et al. (2011) who concluded that the amplitudes of the annual cycle in the Mediterranean Sea vary between 4.0 and $11.00 \mathrm{~cm}$. The $\mathrm{M}_{2}$ constituent is the key player in the observed astronomical variations, and reaches its maximum in the eastern part of the coast. Amplitudes and phases of the different tidal constituents in the present study are in a very good agreement with those previously concluded for AWH (Moursy 1998, Tayel 2008, Hussein et al. 2010) AQ (El-Geziry 2013) and PS (Moursy 1998, Tonbol and Shaltout 2013). This is the first study of these characteristics off El-Burullus, Sidi Abdel-Rahman and Mersa Matrouh. As such, there was no reference upon which to compare the present work.

The MSL over the different periods of records at each location was calculated. Results revealed very significant variations in the MSL, with a general slope of declination from east (PS) to west (MM) along the Egyptian Mediterranean Coast. 
This agrees with the general atmospheric pressure scheme of Lows and Highs over the Levantine Basin (Tsimplis et al. 2005, Gomis et al. 2008, Oddo et al. 2014).

Analysed tide-gauge data showed that the rate of increase in the sea level is not evenly distributed along the Egyptian Mediterranean Coast. The overall average rate of SLR along the Egyptian Mediterranean coast is calculated to be about $3.4 \mathrm{~mm} / \mathrm{yr}$. However, it worth mentioning that the mid-to-east part (AQ, $\mathrm{BR}$ and PS) of the coast examines higher rates than its mid-to-west part (AWH, $\mathrm{SAR}$ and $\mathrm{MM}$ ). This may be attributed to the pronounced land subsidence taking place in this eastern region of the Egyptian Mediterranean coast. This also comes in agreement with the conclusion of Frihy (2003) who assessed the exposure of the Nile Delta coastal zone to the SLR consequences and identified four main sections along the Nile Delta Coast as most vulnerable to SLR including; Burullus and Manzala lakes, western backshore zone of Abu Qir Bay, Manzala-Port Said area, and Ras El-Barr Beach. His study estimated that about $30 \%$ of the Nile Delta coast would be vulnerable to SLR. Moreover, the present results open the door for further investigation on the key factors affecting this part of the Egyptian Mediterranean coast, especially the land subsidence rates. Recent observations of the subsidence rate at Alexandria using permanent GPS (Woppelmann and Marcos 2012) showed moderate values of $-0.4 \pm 0.2 \mathrm{~mm} /$ year. Maiyza and El-Geziry (2012) concluded that the rate of sea level variation off the Egyptian Mediterranean coast is controlled not only by the oceanographic factors but also by the land subsidence process, which has much more impact $(2 / 3)$ than the former $(1 / 3)$. Larger rates of subsidence were observed at the eastern part of the Nile Delta off Port Said, which is subsiding at $5 \mathrm{~mm} / \mathrm{yr}$ and, SLR and its potential impacts would therefore become more severe than other parts of the Nile Delta (El-Raey 1997). Comparing projected $21^{\text {st }}$ century SLR and digital elevation data indicates that the Nile Delta region will not remain safe from flooding during the current century without effective adaptation measures, such as shore protection, emission reductions, and integrated coastal-zone management (Shaltout et al. 2015).

The seasonal variations of the sea level along the Egyptian Mediterranean coast examine a seasonal trend with low values in spring season and higher ones in summer. This is in agreement with the conclusions of Moursy (1994). Further investigation on the oceanographic and meteorological factors, is a must; in order to get more comprehensive idea about the mechanism of seasonality and to build robust conclusion on these variations.

So, in conclusion, the Egyptian Mediterranean coast is vulnerable to the sea level rise. However, its mid-to-east part is much more vulnerable to this rise than its mid-to-west part. The flooding risk assessment of this region, comprising the Nile Delta, is a must for designing plans of coastal defence and protection. More research is needed on the oceanographic and meteorological forces impacting on the seasonality of variations in the sea level along the Egyptian Mediterranean coast. Also, the present study strongly recommends more investigation on the land subsidence rates along the coast in general and off the Nile Delta in particular. 


\section{References}

Cazenave A, Cabanes C, Dominh K, Mangiarotti S (2001) Recent sea level changes in the Mediterranean Sea revealed by TOPEX/POSEIDON satellite altimetry. Geophysical Research Letters 28(8): 1607-1610.

Church JA, White NJ (2006) A $20^{\text {th }}$ century acceleration in global sea-level rise. Geophysical Research Letters 33(1): L01602.

Church JA, White NJ (2011) Sea-level rise from the late $19^{\text {th }}$ to the early $21^{\text {st }}$ Century. Surveys in Geophysics 32(4-5): 585-602.

Dasgupta S, Laplante B, Murray S, Wheeler D (2009) Sea-Level Rise and Storm Surges: A Comparative Analysis of Impacts in Developing Countries. The World Bank, Policy Research Working Paper, WPS4901, 41p. Available at: http://documents.worldbank. org/curated/en/657521468157195342/Sea-level-rise-and-storm-surges-a-compara tive-analysis-of-impacts-in-developing-countries.

Douglas BC (2001) Sea level change in the era of the recording tide gauge. In BC Douglas, MS Kearney, SP Leatherman (eds) Sea Level Rise, History and Consequences, 3764. USA: Academic Press, San Diego, CA.

El-Deberky Y, Hunicke B (2015) Vulnerability of the Nile Delta to recent and future climate change. In Proceedings of the $36^{\text {th }}$ IAHR World Congress, the Netherlands, 28 June - 3 July, 2015, 1-7.

El-Fishawi NM, Fanos AM (1989) Prediction of sea-level rise by 2100, Nile delta coast. INQUA, Commission on Quaternary Shorelines, Newsletter 11:43-47.

El-Geziry TM (2013) General Pattern of Sea Level Variation in front of Alexandria (Egypt) and its Relationship to the Wind Pattern. Egyptian Journal of Aquatic Research 39(3): 133-139.

El-Geziry T, Radwan A (2012) Sea level analysis of Alexandria, Egypt. Egyptian Journal of Aquatic Research 38(1): 1-5.

El-Raey M (1997) Vulnerability assessment of the coastal zone of the Nile delta, Egypt, to the impacts of sea level rise. Ocean \& Coastal Management 37(1): 29-40.

El-Raey M (2010) Impacts and Implications of Climate Change for the Coastal Zones of Egypt. In D Michel, A Pnadya (eds) Coastal zones and climate change, 31-50. Washington DC, USA: The Henry L. Stimson Center.

El-Raey M, Frihy O, Nasr S, Desouki S, Dewidar K (1999) Vulnerability assessment of sea level rise over Port Said Governorate, Egypt. Environmental Monitoring and Assessment 56(2): 113-128.

El-Sharkawy H, Rashed H, Rached I (2009) Climate changes: The impacts of sea level rise on Egypt. $45^{\text {th }}$ ISOCARP Congress, 11p. Available at: http://www.isocarp.net/ Data/case_studies/1456.pdf.

Frihy OE (1992) Sea-level rise and shoreline retreat of the Nile delta promontories, Egypt. Natural Hazards 5(1): 65-81.

Frihy OE (2003) The Nile delta-Alexandria coast: vulnerability to Sea-level rise, consequences and adaptation. Mitigation and Adaptation Strategies for Global Change 8(2): 115-138.

Frihy OE, Lotfy MF (1994) Mineralogy and Textures of Beach Sands in Relation to Erosion and Accretion along the Rosetta Promontory of the Nile Delta, Egypt. Journal of Coastal Research 10(3): 588-599.

Gill AE, Niiler PP (1973) The theory of the seasonal variability in the ocean. Deep-sea Research 20(2): 141-177.

Gomis D, Tsimplis MN, Martin-Miguez B, Ratsimandresy AW, Garcia-Lafuente J, Josey SA (2006) Mediterranean Sea level and barotropic flow through the Strait of 
Gibraltar for the period 1958-2001 and reconstructed since 1659. Journal of Geophysical Research 111.Doi:10.1029/2005JC003186 .

Gomis D, Ruiz S, Sotillo MG, Álvarez-Fanjul E, Terradas J (2008) Low frequency Mediterranean Sea level variability: The contribution of atmospheric pressure and wind. Global and Planetary Change 63(2-3): 215-229.

Hussein M, Moursy Z, Tayel M (2010) General pattern of Alexandria western harbor sea level change. JKAU: Marine Science 21(2): 47-61.

Klein M, Lichter M, Zviely D (2004) Recent sea level changes along Israeli and Mediterranean coasts. Horizons in Geography Special Issues 60-61: 167-176.

Kowalik Z, Luick J (2013) The Oceanography of Tides, 157. USA: University of Alaska.

Larnicol G, Ayoub N. Le Trayon PY (2002) Major changes in Mediterranean Sea level variability from 7 years of TOPEX/Poseidon and ERS-1/2 data. Journal of Marine Systems 33-34: 63-89.

Maiyza IA, El-Geziry TM (2012) Long term sea-level variation in the south-eastern Mediterranean Sea: A new approach of examination. Journal of Operational Oceanography 5(2): 53-59.

Moursy ZA (1994) Seasonal fluctuation of surge height at Alexanderia, Egypt. National Institute of Oceanography and Fisheries 20(1): 33-42.

Moursy Z (1998) Characteristics of the tides at the two main harbors of Egypt. JKAU: Marine Science 9(1): 19-27.

Oddo P, Bonaduce A, Pinardi N, Guarnieri A (2014) Sensitivity of the Mediterranean sea level to atmospheric pressure and free surface elevation numerical formulation in NEMO. Geoscientific Model Development 73001-3015 Available at: https://doi.org/ 10.5194/gmd-7-3001-2014.

Passaro M, Seitz F (2012) Steric sea level variations in the central-eastern Mediterranean Sea from Argo observations. Bollettino di Geofisica Teorica ed Applicata 52(1): 131147.

Pawlowicz R, Beardsley B, Lentz S (2002) Classical tidal harmonic analysis including error estimates in MATLAB using T_TIDE. Computers \& Geosciences 28(8): 929937.

Pugh DT (2004) Changing sea levels: Effects of tides, weather and climate, 280p. UK: Cambridge University Press.

Pugh D, Woodworth PH (2014) Se-level Science: Understanding tides, surges, tsunamis and mean sea level, 395. UK: Cambridge University Press.

Radwan A, El-Geziry T (2013) Some statistical characteristics of surges at Alexandria, Egypt. JKAU: Marine Science 24(2): 31-38.

Rosen DS (2002) Long term remedial measures of sedimentological impact due to coastal developments on the southeastern Mediterranean coast. In The Changing Coast (EUROCOAST/EUCC Ed.), 2, 322-331. Available at: https://bit.ly/2kRqqZa.

Saad NN, Moursy ZA, Sharaf El-Din SH (2011) Water heights and weather regimes at Alexandria Harbor. International Journal Physical Science 6(30): 7035-7043.

Said MA, Moursy ZA, Radwan AA (2012) Climatic change and sea level oscillations off Alexandria, Egypt. In Proceedings of International Conference on Marine and Coastal Ecosystems, Albania, 353-359.

Santamaria RM, Farouk M (2011) Study area characterisation. In: Integrated Coastal Zone Management plan for the coastal areas between Marsa Matruh and El-Sallum, Egypt, Vo. 1 (Environmental Hydraulics Institute "IH Cantabria" eds), 16-39.

Shaker AA, Saad AA, Al-Naggar D, Faisal H (2011) Absolute sea-level rise estimation at Alexandria using tide records and GPS observations. FIG Working Week 2011, Bridging the gap between Cultures, Marrakech, Morocco, 18-22 May 2011, 14p. Available at: https://bit.ly/2kUWPhF. 
Shaltout M, Tonbol K, Omstedt A (2015) Sea-level change and projected future flooding along the Egyptian Mediterranean coast. Oceanologia 57(4): 193-307.

Shirman B (2001) Israel coast sea level changes during 1958-2001. Survey of Israel, Report No. RD4/1, 17p.

Syvitski JPM, Kettner AJ, Overeem I, Hutton EWH, Hannon MT, Brakenridge GR, Day J, Vörösmarty C, Saito Y, Giosan L, Nicholls RJ (2009) Sinking deltas due to human activities. Nature Geoscience, 2: 681-686.

Tayel MF (2008) Using Artificial Intelligence (AI) Techniques for Tidal Level Forecasting at Alexandria Western Harbor. MSc Thesis, Faculty of Science, University of Alexandria, Egypt, 114p.

Torres RR, Tsimplis MN (2012) Seasonal sea level cycle in the Caribbean Sea. Geophysical Research Letters. Doi:10.1029/2012JC008159 .

Tsimplis MN (2002) Sea level in the Mediterranean Sea: The contribution of temperature and salinity changes. Geophysical Research Letters 29(23): 1-4.

Tsimplis MN, Baker TF (2000) Sea level drop in the Mediterranean Sea: an indicator of deep water salinity and temperature changes. Geophysical Research Letters 27(12): 1731-1734.

Tsimplis MN, Josey SA (2001) Forcing of the Mediterranean Sea by atmospheric oscillations over the North Atlantic. Geophysical Research Letters 28(5): 803-806.

Tsimplis MN, Alvarez-Fanjul E, Gomis D, Fenoglio-Marc L, Perez B (2005) Mediterranean Sea level trends: Atmospheric pressure and wind contribution. Geophysical Research Letters 32:20.. Doi:10.1029/2005GL023867 .

Tsimplis M, Marcos M, Somot S, Barnier B (2008) Sea level forcing in the Mediterranean Sea between 1960 and 2000. Global and Planetary Changes 63(4): 325-332.

Tonbol K, Shaltout M, (2013) Tidal and Non- Tidal Sea Level off Port Said, Nile Delta, Egypt. JKAU: Marine Sciences 24(2): 69-83.

UNDP (2011) Egypt's National Strategy for Adaptation to Climate Change and Disaster Risk Reduction. United Nations Development Program, 166. Available at: http://www.climasouth.eu/docs/Adaptation011\%20StrategyEgypt.pdf.

UNDP (2014) Adaptation to Climate Change in the Nile Delta through Integrated Coastal Zone Management. United Nations Development Program, 73p. Available at: https://bit.ly/2mkSuoc.

Vigo MI, Sánchez-Realesa JM, Trottini M, Chaoc BF (2011) Mediterranean Sea level variations: Analysis of the satellite altimetric data, 1992-2008. Journal of Geodynamics 52(3-4): 271-278.

Woppelmann G, Marcos M (2012) Coastal sea level rise in southern Europe and the nonclimate contribution of vertical land motion. Journal Geophysical Research Letters 117:1). Doi:10.1029/2011JC007469. 